\title{
不規則な地震動による動水圧
}

\author{
准員小坪清 真*

\section{DYNAMIC WATER PRESSURE ON DAMS DUE \\ TO IRREGULAR EARTHQUAKES}

(Trans. JSCE, No. 47, Aug. 1957)

Seima Kotsubo, C.E. Assoc. Member

Synopsis: A theory of dynamic water pressures due to irregular earthquakes was deduced and an example of computation was shown.

The result shows that the dynamic water pressures calculated by the author's theory are much different from those obtained on the assumption that the earthquakes are stationary simple harmonic motions.

要旨 全く不規則な地震動による動水圧の理論式を導いて計算例を示し，その結果が，地震動を定常的な単弦 振動と仮定して求めた從来の動水圧の性状と，はなはだ異なるるのであることを示した。

緒論 従来の動水圧理論式 ${ }^{122}$ は, 地震動が定常的な単弦振動であると仮定して解かれたものである。しかしな がら, 実際の地震動は, 突然起る全く不規則な週期及び振幅をるつ震動の重合である。従つて, 厳密には, これ は，刻々変化する動水圧の過渡現象として解かれねね゙ならない。

この場合, 不規則な地艋の震動とともない, ダム自身も複雑な弾性変形を行なうのであるから, ダムと䝪水と の連成振動として取り报うべきすのであるが, この問題は, 「貯水時に和けるダムの弾性振動」として, 別の機会 そ論ずることにし，本論文では，ダムが地盤と共に剛振動をなするのとして動水圧を求めた。

広い領域をもつ弾性体内の過渡現象は，一般飞波動問題として取り扱われる。音の水中伝播速度は約 $1400 \mathrm{~m} / \mathrm{s}$ であり, 地震は少くとも数秒間は続くものであるから, 貯水池の長さが短かい場合には反射波の取り扱いが必要 になる。しかしながら，実際の眝水池の形は簡単なるのではないから，反射波る極めて複雑なるのとなるである う。亲た, 音波のエネルギーは, 伝播途中に特いて散逸し, 上流側境界で反射して再びダム地点まで到達するま でには，相当減衰したものとなるであるう。これらの理由により，問題の取り扱いを簡単にするために，本論文 では，反射波の取り报いを省略し，貯水池が上流側へ無限に広がるものと仮定した。

\section{[I ] 二次元動水圧}

\section{1. 微分方程式及び境界条件}

図一1 示すように， $x$ 及び $z$ を直角座標， $h$ を堤高， $u$ 及び $w$ を， $x$ 及

図一1 重カダム

Fig.1 Gravity Dam び $z$ 方向の水分子の微小変位, $w_{0}$ を水の単位重量, $E_{v}$ を先の体積弹性率, $g$ 重力加速度, $t$ 学時間, $\sigma$ を動水压とすれば, 水分子の運動方程式ふ次の よう汭る。

$$
\begin{aligned}
& \frac{\partial^{2} u}{\partial t^{2}}=-\frac{g}{w_{0}} \frac{\partial \sigma}{\partial x} \ldots \ldots \\
& \frac{\partial^{2} w}{\partial t^{2}}=-\frac{g}{w_{0}} \frac{\partial \sigma}{\partial z} \ldots . . \\
& \sigma=-E_{v}\left\{\frac{\partial u}{\partial x}+\frac{\partial w}{\partial z}\right\}
\end{aligned}
$$

今,

$$
\frac{\partial u}{\partial t}=-\frac{\partial \phi}{\partial x}, \frac{\partial w}{\partial t}=-\frac{\partial \phi}{\partial z}
$$

なる速度ポテンシャル申を用いると，(1)，(2) 及び (3) 式より，次の幑分方程式が得られる。

$$
\frac{\partial^{2} \varphi}{\partial x^{2}}+\frac{\partial^{2} \phi}{\partial z^{2}}-\frac{w_{0}}{g E_{v}} \frac{\partial^{2} \phi}{\partial t^{2}}=0
$$

動水圧のみを考学ると， $t=0$ 亿杼いては，速度ポテンシャル及び動水圧は 0 である。また，実際のダムでは，

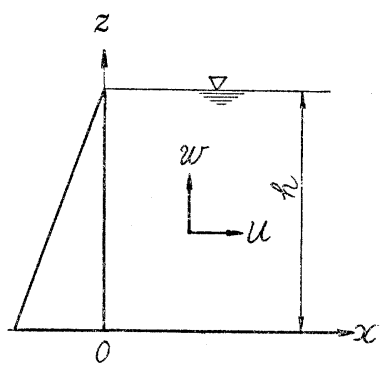

\footnotetext{
* 九大大学院研究桨学生, 工学部土木教室
} 
表面波の影響は極めて微小であるから，その取披を省略すると，境界条件は次のようになる。

$\begin{array}{ll}\text { (i ) } & \left(\frac{\partial \phi}{\partial z}\right)_{z=0}=0,(\sigma)_{z=h}=\frac{w_{0}}{g}\left(\frac{\partial \phi}{\partial t}\right)_{z=h}=0 \\ \text { (i i) } & \left(\frac{\partial \phi}{\partial x}\right)_{x=0}=f(t) \\ \text { (iii) } & (\phi)_{t=0}=0, \frac{w_{0}}{g}\left(\frac{\partial \phi}{\partial t}\right)_{t=0}=0\end{array}$

微分方程式 (4)を, $t$ について Laplace 変換を行う(第2 種)。

$$
\begin{aligned}
& \mathfrak{S}(\phi)=\mathscr{D}(\boldsymbol{x}, \boldsymbol{z}, \boldsymbol{p}) \\
& \begin{aligned}
\mathfrak{Q}\left(\frac{\partial^{2} \phi}{\partial t^{2}}\right) & =p^{2} \Phi-p^{2}(\phi)_{t=0}-p\left(\frac{\partial \phi}{\partial t}\right)_{t=0} \\
& =p^{2} \Phi
\end{aligned}
\end{aligned}
$$

であるから，(4) 式は，次のようとなる。

$$
\frac{\partial^{2} \Phi}{\partial x^{2}}+\frac{\partial^{2} \Phi}{\partial z^{2}}-\frac{w_{0} p^{2}}{g E_{v}} \Phi=0
$$

境界条件 (5) 式は次のようになる。

$$
\left.\begin{array}{ll}
\text { (i) } & \left(\frac{\partial \Phi}{\partial z}\right)_{z=0}=0,(\Phi)_{z=h}=0 \\
\text { (i i) } & \left(\frac{\partial \Phi}{\partial x}\right)_{x=0}=\mathfrak{R} f(t)
\end{array}\right\}
$$

\section{2. 微分方程式の解}

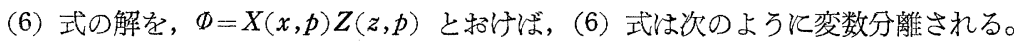

$$
\begin{aligned}
& \frac{d^{2} Z}{d z^{2}}+\lambda^{2} Z=0 \\
& \frac{d^{2} X}{d x^{2}}-\left(\lambda^{2}+\frac{w_{0} p^{2}}{g E_{v}}\right) X=0
\end{aligned}
$$

条件 (7) 式の (i) を満足する (8) 式の解は,

$$
Z=A_{m} \cos \lambda_{m} z, \quad \lambda_{m}=\frac{(2 m+1) \pi}{2 h}, \quad(m=0,1,2, \cdots \cdots \cdots \cdots)
$$

$\lambda_{m}$ は実数， $p$ は一般に複素数であるから，(9) 式の解は，次のようとなる。

$$
X=B \boldsymbol{e}^{-x \sqrt{\lambda m^{2}+\left(\frac{p}{v}\right)^{2}}}+C e^{x} \sqrt{\lambda m^{2}+\left(\frac{p}{v}\right)^{2}}
$$

ここに, $v=\sqrt{g E_{v} / w_{0}}=$ 音速である。この解の第 2 項は, $x \rightarrow \infty$ で発散するから, 解として第 1 項のみを取れ ば，解 $Ф$ は次のような形となる。

$$
\Phi=\sum_{m=0}^{\infty} A_{m} \cos \lambda_{m} z \cdot e^{-x} \sqrt{\lambda^{2} m+\left(\frac{p}{v}\right)^{2}}
$$

(a) $f(t)=-1$ なる場合

ダムが，単位跳躍函数 1 で表わされる衝撃速度を受けた場合には，境界条件 (7) 式の（ii）は次のようになる。

$$
\left.\begin{array}{rlrl}
\left(\frac{\partial \Phi}{\partial x}\right)_{x=0} & =-1 & & t>0 \\
& =0 & & t<0
\end{array}\right\}
$$

この条件を用いて，(10)式の係数 $A_{m}$ を求めると，のが次式となる。

$$
\Phi=\sum_{m=0}^{\infty} \frac{4(-1)^{m} \cos \lambda_{m} z e^{-x} \sqrt{\lambda_{m^{2}+\left(\frac{p}{v}\right)^{2}}} \cdot 1}{(2 m+1) \pi \sqrt{\lambda_{m}^{2}+\left(\frac{p}{v}\right)^{2}}}
$$

従つて動水圧々，

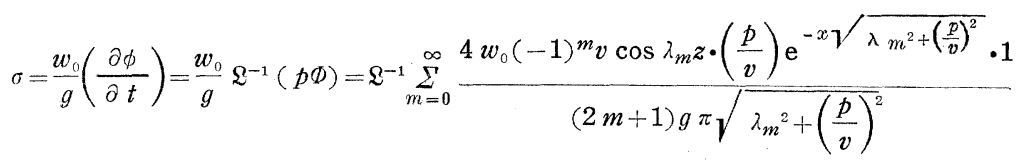




$$
\left.\begin{array}{rlr}
\sigma & =\sum_{m=0}^{\infty} \frac{4 w_{0}(-1)^{m} v \cos \lambda_{m} z \cdot J_{0}\left(\lambda_{m} \sqrt{(v t)^{2}-x^{2}}\right)}{(2 m+1) g \pi} & (v t>x) \\
& =0 & (v t<x)
\end{array}\right\} .
$$

(b) 速度時間曲線 $V(t)$ が与兄られた場合

図一2 のように, 速度 $V$ が, $\tau=0$ の時 $V(0)$ まで跳躍し, その後図の 曲線沿うて進むものとする。これを， $d V$ の各段階分け，この分け方 を密注すれ゙, 個々の段階は $d V \cdot 1$ の跳躍速度を意味することになる。単 位跳躍速度飞よる動水圧は， $\sigma=F(t)$ であるから， $d V$ とより $d \sigma$ なる寄 与があるものとすれば

$$
\begin{aligned}
d \sigma & =d V \cdot F(t-\tau) \\
& =\frac{d V}{d \tau} \cdot F(t-\tau) d \tau
\end{aligned}
$$

これらの笴与を， $\tau=0$ から $\tau=t$ まで積分すれば

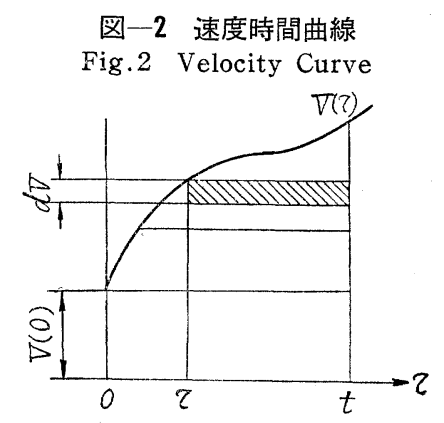

$$
\left.\begin{array}{rl}
\sigma(t) & =V(0) F(t)+\int_{0}^{t} \frac{d V(\tau)}{d \tau} \cdot F(t-\tau) d \tau \\
& =V(t) F(0)+\int_{0}^{t} V(t-\tau) \frac{d}{d \tau} F(\tau) d \tau
\end{array}\right\}
$$

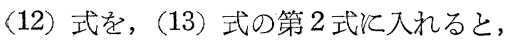

$$
\sigma=-\sum_{m=0}^{\infty} \frac{4 w_{0}(-1)^{m} v \cos \lambda_{m} z}{(2 m+1) g \pi}\left\{V(t)+\int_{\frac{x}{v}}^{t} V(t-\tau) \frac{d}{d \tau} J_{0}\left(\lambda_{m} \sqrt{v^{2} \tau^{2}-x^{2}}\right) d \tau\right\}
$$

(c) 地動が突然 $\cos \omega t$ で始まる場合

$$
(v \tau>x)
$$

地震動を $\left(\alpha g / \omega^{2}\right) \cos \omega t$ とすれば,

$$
V=-\frac{\alpha g}{\omega} \sin \omega t, \frac{d V}{d t}=-\alpha g \cos \omega t
$$

となるから，(13）式の第1式を用いて，動水圧 $\sigma$ が次式で表わされる。

$$
\begin{array}{r}
\sigma=-\sum_{m=0}^{\infty} \frac{4 \alpha w_{0}(-1)^{m} v \cos \lambda_{m} z}{(2 m+1) \pi} \int_{\frac{x}{v}}^{t} \cos \omega(t-\tau) J_{0}\left(\lambda_{m} \sqrt{(v \tau)^{2}-x^{2}}\right) d \tau \\
\left(t>\frac{x}{v}\right)
\end{array}
$$

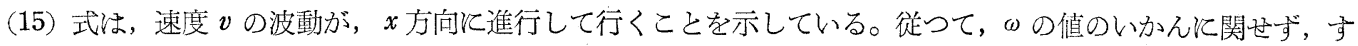
べての項を採用しなければならない。

$\omega=\lambda_{m} v$ のとき，ダムに作用する動水圧ね，Kapteyn's trigonometrical integral ${ }^{3}$ を用いて，

$$
\int_{0}^{t} \cos \omega(t-\tau) J_{0}\left(\lambda_{m} v \tau\right) d \tau=t J_{0}\left(\lambda_{m} v t\right)
$$

(16) 式は, この mode の動水圧吕時閒の経過と共に限りなく増大してゆく状態を示している。すなわち, こ のときほ，動水圧は地動に共振したのであつて，定常振動論に括ける共振条件と一致する。

(15) 式を定常項と過渡項飞分離すると,

$$
\begin{gathered}
\int_{\frac{x}{v}}^{t} \cos \omega(t-\tau) J_{0}\left(\lambda_{m} \sqrt{(v \tau)^{2}-x^{2}}\right) d \tau \\
=\cos \omega t \int_{\frac{x}{v}}^{\infty} \cos \omega \tau \cdot J_{0}\left(\lambda_{m} \sqrt{(v \tau)^{2}-x^{2}}\right) d \tau+\sin \omega t \int_{\frac{x}{v}}^{\infty} \sin \omega \tau \cdot J_{0}\left(\lambda_{m} V \overline{(v \tau)^{2}-x^{2}}\right) d \tau \\
\quad-\int_{t}^{\infty} \cos \omega(t-\tau) \cdot J_{0}\left(\lambda_{m} \sqrt{(v \tau)^{2}-x^{2}}\right) d \tau \\
\text { 第 } 1 \text { 項 }=\cos \omega t \int_{0}^{\infty} \frac{\cos \left(\omega \sqrt{\xi^{2}+\left(\frac{x}{v}\right)^{2}}\right)}{\sqrt{\xi^{2}+\left(\frac{x}{v}\right)^{2}}} \xi J_{0}\left(\lambda_{m} v \xi\right) d \xi, \text { 第 } 2 \text { 項 }=\sin \omega t \int_{0}^{\infty} \frac{\sin \left(\omega \sqrt{\xi^{2}+\left(\frac{x}{v}\right)^{2}}\right)}{\sqrt{\xi^{2}+\left(\frac{x}{v}\right)^{2}}}
\end{gathered}
$$


次の公式

を用いれば，

$$
\int_{0}^{\infty} J_{0}(a t) \frac{\mathrm{e}^{-b \sqrt{t^{2}+z^{2}}}}{\sqrt{\overline{t^{2}+z^{2}}}} t d t=\frac{\mathrm{e}^{-z v \overline{a^{2}+b^{2}}}}{\sqrt{a^{2}+b^{2}}}
$$

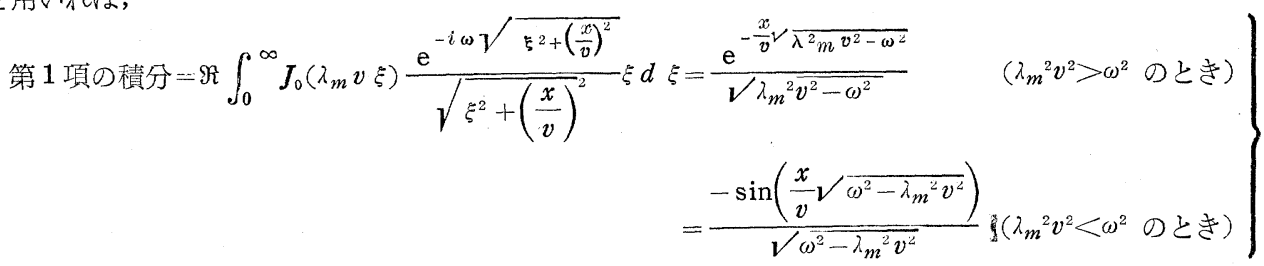

第 2 項の積分 $=-\Im \int_{0}^{\infty} J_{0}\left(\lambda_{m} v \xi\right) \frac{\mathrm{e}^{-i \omega \sqrt{\xi^{2}+\left(\frac{x}{v}\right)^{2}}}}{\sqrt{\xi^{2}+\left(\frac{x}{v}\right)^{2}}} \xi d \xi=0 \quad\left(\lambda_{m} v^{2}>\omega^{2}\right.$ のとき)

$$
=\frac{\cos \left(\frac{x}{v} \sqrt{\omega^{2}-\lambda_{m}{ }^{2} v^{2}}\right)}{\sqrt{\omega^{2}-\lambda_{m} v^{2}}}\left(\lambda_{m}^{2} v^{2}<\omega^{2} \text { のとき }\right)
$$

第 1 項, 第 2 項を統合すると, 結局, 動水圧 $\sigma$ が次式となる。

$$
\begin{aligned}
\sigma=-\sum_{m=0}^{s-1} & \frac{4 \alpha w_{0}(-1)^{m} \cos \lambda_{m} z}{(2 m+1) \pi \sqrt{c^{2}-\lambda_{m}^{2}}} \sin \left(\omega t-x \sqrt{c^{2}-\lambda_{m}^{2}}\right) \\
& -\sum_{m=s}^{\infty} \frac{4 \alpha w_{0}(-1)^{m} \cos \lambda_{m} z}{(2 m+1) \pi \sqrt{\lambda_{m}^{2}-c^{2}}} \mathrm{e}^{-x V \overline{\lambda_{m^{2}-c^{2}}}} \cos \omega t \\
& +\sum_{m=0}^{\infty} \frac{4 \alpha w_{0}(-1)^{m} v \cos \lambda_{m} z}{(2 m+1) \pi} \int_{t}^{\infty} \cos \omega(t-\tau) J_{0}\left(\lambda_{m} V \overline{(v \tau)^{2}-x^{2}}\right) d \tau .
\end{aligned}
$$

ここそ, $\quad c^{2}=(\omega / v)^{2}=\left(w_{0} \omega^{2} / g E_{v}\right), \quad S$ は， $\lambda_{m}^{2}>c^{2}$ を満足する $m$ の最小值である。

(17) 式の第 1 項及び第 2 項が定常項, 第 3 項が過渡項である。 地動の週期が動水圧の共振週期より大きい時《は，第 1 項はなく なり，地動と同一位相の動水圧となる。地動の週期が動水圧の共 振週期より小さい時には，第 1 項子残り，地動の位相上り $90^{\circ}$ 招 くれた動水圧が生ずる。従来の定常振動論による動水圧式では, 第 2 項のみを採用し, 第 1 項をすてたのであるが, この項も, や はり解として採用しなければならない。

図一3 注, 堤高 $h=100 \mathrm{~m}$ のダムに対し, 地震週期 $T$ が 1.0 $\mathrm{sec}, 0.5 \mathrm{sec}, 0.278 \mathrm{sec}$ (共振週期) 及び $0.2 \mathrm{sec}$ の時の, 堤底 動水圧を, 時間 $t=0$ から $t=1.0 \mathrm{sec}$ まで図示したものである。 但し, $\sigma=4 \alpha w_{0} h Q$ の形飞要約し, 無次元の係数 $Q$ の変化で示 した。な招, 図中の点線は, 定常振動として解かれた従来の動水 圧である。

図から明らかなよろに，T=1.0 sec の時には, 動き始めに和け る動水圧は，定常振動の動水圧よりも約 $30 \%$ 大きく， $T=0.5$ $\sec$ の時には, 約 $40 \%$ 大きい。

地震週期が共振週期飞一致した時には, 動水圧は震動時間の経 過と共飞次第に大きくなり, 第 2 動目に特いて $Q=0.4$ となつて Wる。従つて, ダム地点の地震動の卓越週期が, 動水圧の共振週 期に等しい時には, 相当大きな動水圧を惹起することが予想され る。

地震週期が共振週期より短かい場合には，定常振動論飞よれば， 動水圧は，はなはだ小さいものであるが，本論によれば相当大き な值を示し, かつ, 地動の位相よりほぼ $90^{\circ}$ 扮くれていることが わかる。

\section{図一3 地動が $\cos \omega \mathrm{t}$ で始まる時の過渡動水} 圧

Fig.3 Transient Dynamic Water Pressure When Earthquake Begins with $\cos \omega t$
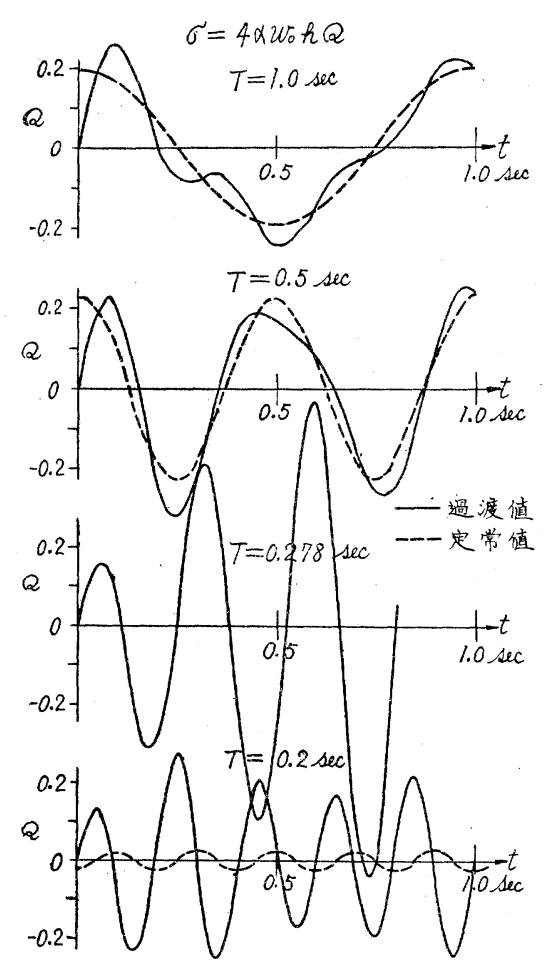
(d) 地震加速度記録 $A(t)$ が与兄られた場合

(13) 式の第1式佀 (12) 式を入れて

$$
\sigma=\sum_{m=0}^{\infty} \frac{4 w_{0}(-1)^{m} v \cos \lambda_{m} z}{(2 m+1) g \pi}\left\{V(0) J_{0}\left(\lambda_{m} V \overline{(v t)^{2}-x^{2}}\right)+\int_{\frac{x}{v}}^{t} A(t-\tau) J_{0}\left(\lambda_{m} V \overline{(v \tau)^{2}-x^{2}}\right) d \tau\right\}
$$

地震に抒いては，一般に， $V(0)=0$ と招くことができるから，

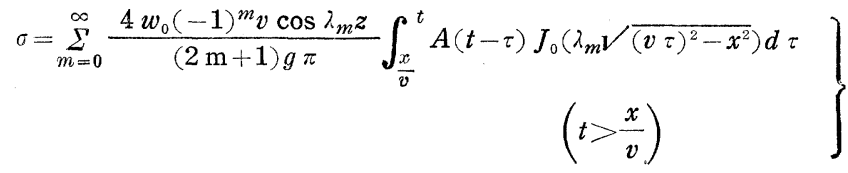

加速度曲線の加速度の最大值を $\propto g$ とし，この最大值を 1 としたときの他の時刻と淤ける加速度を $\psi(t)$ で 表わせば， $A(t)=\alpha g \psi(t)$ となり，(18) 式は，

$$
\begin{array}{cc}
\sigma=\sum_{m=0}^{\infty} \frac{4 \alpha w_{0} h(-1)^{m} v \cos \lambda_{m} z}{(2 m+1) \pi h} \int_{\frac{x}{v}}^{t} \psi(t-\tau) J_{0}\left(\lambda_{m} V \overline{(v \tau)^{n}-x^{2}}\right) d \tau \\
\equiv 4 \propto w_{0} h Q \quad\left(t>\frac{x}{v}\right)
\end{array}
$$

従来の定常振動論による動水圧と，(19）式によつて計算される動水圧とを，無次元の係数 $Q$ の值の变化で比 較することができる。

写真一1は，塚原ダムサイトで記録された地震加速度曲線で，電力研究所報より取つたものである。図一4 は， 一例としてこのような地震とよ つて生ずる動水圧を，(19）式

写真一1 塚原ダムサイト地震記録

(1954.2.23)

そよつて計算したものである。 図の最上段は, 従来の定常振動

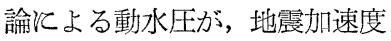
と同一位相で，刻々に和ける地 震加速度比例して生ずると見 た場合の值で，その最大值を 1 とした。

図-4から次のことがわかる。

（1）要る時刻治打る動水 压は，先の時刻の地震加速度に 必ずしも比例するものでなく， 動水压の共振週期と地震週期之 の関係飞より，共振の時刻及び 大きさが異なる。

(2) $h=100 \mathrm{~m}$ 及び $75 \mathrm{~m}$ いずれの場合にも, 動水圧の最 大值は, 定常振動論飞よる動水 压よりも相当大きい。

$t=1.5 \sim 2.0 \mathrm{sec}$ の間では, $h=75 \mathrm{~m}$ の場合には, 動水圧と 地震加速度注とんぞ同一位相 そあるが， $h=100 \mathrm{~m}$ の場合に は, 動水圧の位相は, 地震加速 度のそれより約 $90^{\circ}$ 拉くれてい る。

（4）地動が停止した後に招 いても，動水圧は急汇0 となる

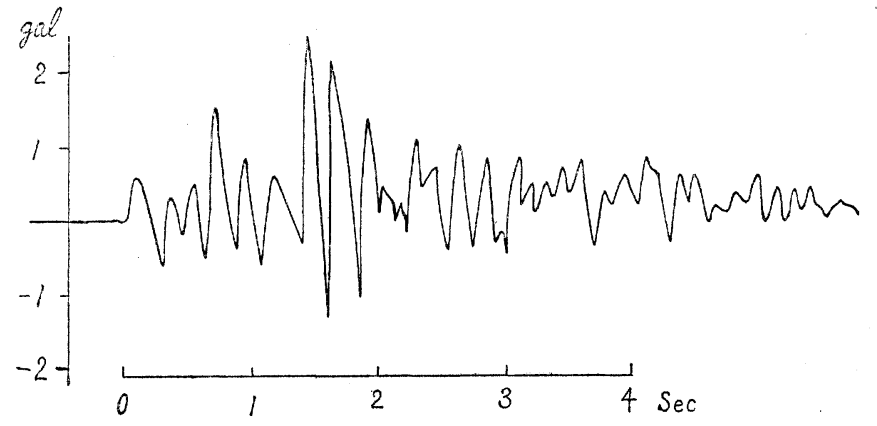

図一4＼cjkstart不規則な地震動による動水圧

Fig.4 Dynamic Water Pressure due to Irregular Earthquake

(a)定常振䡃敦にもとづく近似解

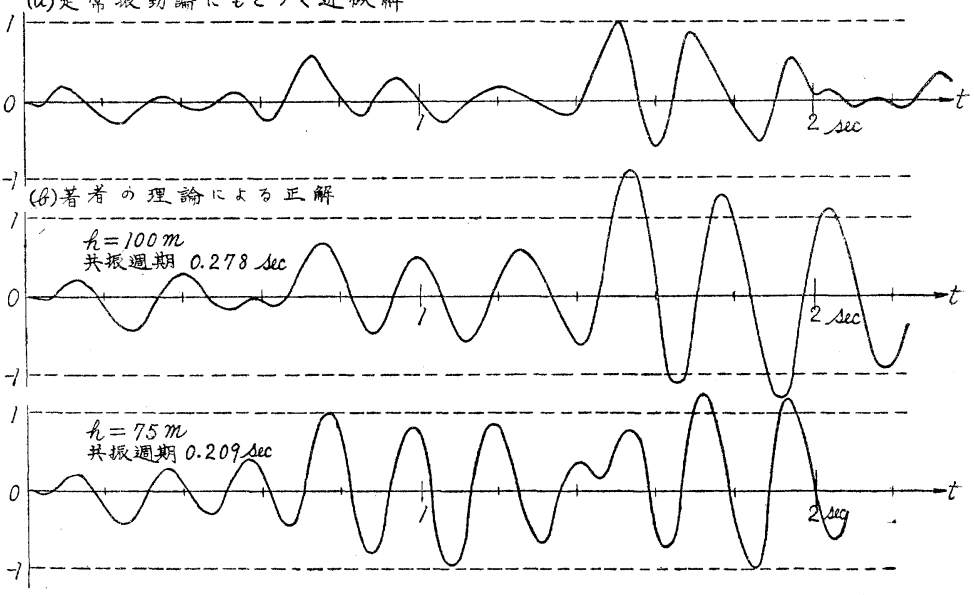
ものではなく，な括しばらく，その固有週期でダムと作用しながら次第に減袁する。

[II] 地 形の 影 
ダム高に比し，河幅が非常に広いか，または，矩形断面の場合には，前述のよろな二次元的取扱が可能である が，ダム地点の横断面形が幅狭い台形あるい情角形をなす場合には，むはや二次元的取扱をすることができな い。このような場合には三次元的動水圧の解が必要になる。しかしながら任意の断面に対して理論的解法を試み ることは，はなはだ困難であるから，本論では，断面が扇形または三角形の場合についての解を求め, 一般の形 の断面の場合を推論する。

1. 扇 形 断 面

図一5 亿示すように, 円筒座標を $\rho, \theta, x$ とし, 水分子の座標方向の微小変位 Fig.5 Fan-shaped Section. をとれぞれ，u,v,w とする。今，

$$
\frac{\partial u}{\partial t}=-\frac{\partial \phi}{\partial \rho}, \frac{\partial v}{\partial t}=-\frac{\partial \phi}{\rho \partial \theta}, \frac{\partial w}{\partial t}=-\frac{\partial \phi}{\partial x}
$$

なる速度ポテンシャル $\phi$ を用いると， $\phi$ 飞関する微分方程式及び動水圧 $\sigma$ が次 のようになる。

$$
\begin{aligned}
& \frac{\partial^{2} \phi}{\partial \rho^{2}}+\frac{1}{\rho} \frac{\partial \phi}{\partial \rho}+\frac{\partial^{2} \phi}{\rho^{2} \partial \theta^{2}}+\frac{\partial^{2} \phi}{\partial x^{2}}-\frac{w_{0}}{g E_{v}} \frac{\partial^{n} \phi}{\partial t^{2}}=0 \\
& \sigma=\frac{w_{0}}{g} \frac{\partial \phi}{\partial t} \ldots \ldots \ldots \ldots \ldots \ldots \ldots \ldots \ldots \ldots \ldots \ldots \ldots \ldots \ldots \ldots \ldots \ldots \ldots \ldots \ldots \ldots \ldots \ldots \ldots \ldots \ldots \ldots \ldots \ldots \ldots
\end{aligned}
$$

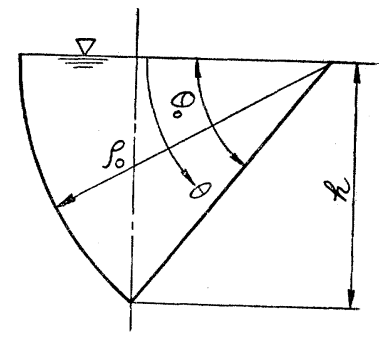

（20）式を解くに㐫たつての境界条件は,

$$
\left(\frac{w_{0}}{g} \frac{\partial \phi}{\partial t}\right)_{\theta=0}=0, \quad\left(\frac{\partial \phi}{\partial \theta}\right)_{\theta=\theta_{0}}=0
$$

(iii) $\left(\frac{\partial \phi}{\partial x}\right)_{x=0}=f(t)$,

(iv)

$$
(\phi)_{t=0}=0, \quad\left(\frac{w_{0}}{g} \frac{\partial \phi}{\partial t}\right)_{t=0}=0
$$

(20) 式を条件 (22) 式飞よつて解けば, $f(t)=-1$ なる場合の解 $\sigma$ 注次式となる。

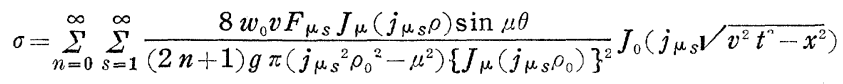

加速度曲線 $\alpha g \psi(t)$ 飞よる動水圧は次式となる。

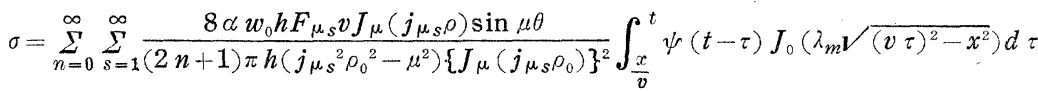

$$
\begin{aligned}
& \left(t>\frac{x}{v}\right)
\end{aligned}
$$

ここに,

$$
\begin{aligned}
& \mu=\frac{(2 n+1) \pi}{2 \theta_{0}},(n=0,1,2, \ldots \ldots \ldots) \\
& F_{\mu_{s}}=\int_{0}^{\boldsymbol{\rho}_{0}} J_{\mu}\left(j_{\mu_{s}} \rho\right) \cdot\left(j_{\mu_{s}} \rho\right) \cdot d\left(j_{\mu_{s}} \rho\right)
\end{aligned}
$$

で, $j_{\mu_{s}}$ 2， $J_{\mu^{\prime}}{ }^{\prime}\left(j \rho_{0}\right)=0$ を満足する $j$ の值で，絶対値小なるものより順次 $s=1,2, \cdots \cdots$ とする。 共振週期は， $\omega=j_{\mu_{s}} v$ のとき，すなわち，

$$
T=\sqrt{\frac{w_{0}}{g E_{v}}} \frac{2 \pi}{j_{\mu s}}
$$

\section{2. 河幅が極めて狭い三角形断面の場合}

この場合には, 図一6 亿示すように, 近似的に扇形断面と仮定すれば, $\rho_{0} \simeq h$ となり，微分方程式は（20）式と全く同一となる。境界条件は，

図一6 三角形断面 Fig. 6 Triangular Section

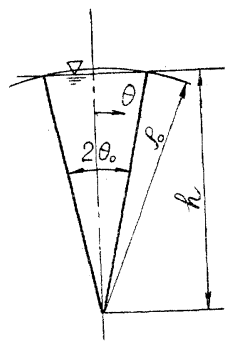


$f(t)=-1$ なる場合の解を求めると, 動水圧 $\sigma$ は次式となる。

$$
\sigma=\sum_{s=1}^{\infty} \frac{4 w_{0} v F_{s} J_{0}\left(j_{s} \rho\right)}{g\left(j_{s} h\right)^{2}\left\{J_{1}\left(j_{s} h\right)\right\}^{2}} J_{0}\left(j_{s} \sqrt{v^{2} t^{2}-x^{2}}\right)
$$

地震加速度曲線 $\alpha g \psi(t)$ そよる動水圧は次式となる。

$$
\begin{gathered}
\sigma=\sum_{s=1}^{\infty} \frac{4 \alpha w_{0} h v F_{s} J_{0}\left(j_{s} \rho\right)}{\left(j_{s} h\right)^{2} h\left\{J_{1}\left(j_{s} h\right)\right\}^{2}} \int_{\frac{x}{v}}^{t} \psi(t-\tau) J_{0}\left(\lambda_{m} \sqrt{(v \tau)^{2}-x^{2}}\right) d \tau \\
\left(t>\frac{x}{v}\right)
\end{gathered}
$$

ここそ， $j_{s}$ は， $J_{0}(j h)=0$ の根で， $F_{s}$ は次式で表わされる。

$$
F_{s}=\int_{0}^{n} J_{0}\left(j_{s} \rho\right) \cdot\left(j_{s} \rho\right) d \cdot\left(j_{s} \rho\right)
$$

共振週期は， $\omega=j_{s} v$ のとき，すなわち，

$$
T=\sqrt{\frac{w_{0}}{g E_{v}}} \frac{2 \pi}{j_{s}}
$$

（24）式及び (28) 式の時間函数は，2 次元の場合の時間函数と同一である。ただ，共振週期とそれ対する振 動型が異なるのみである。

しかしながら，任意の断面に対して，その振動型と共振週期とを求め ることははななだ困難なととである。従つて，実際の応用に便ならし めるため汒，一つの近似解法を考光てみる。表一1 は， $h=100 \mathrm{~m}$ の夕゙ 厶江対乙, (1)矩形断面, (2)半円形断面, (3) $1 / 4$ 円形断面, (4)三角形断面 の場合に拈ける共振週期を示したものである。表から明らかなように， 第 2 次共振週期は, 第 1 次共振週期より遙か、小さい。一般にダム地点 の地震卓越週期は 0.1 0.3 sec であることを考光ると, 実際の地震記 録に対して動水圧を計算する場合, $100 \mathrm{~m}$ 程度以下のダムに対しては第 1 次共振週期のみを取り扱光ば充分であろう。高次の共振週期に対して (19）式の積分を行つても，关の值は極めて小さいものとなるととが予 想される。

今, 断面の平均水深を $\bar{h}$, 最大水深を $h$, 最大水深汶対する二次元的共 振週期を $T$ とすれば, その断面の第 1 次共振週期は, 近似的江 $T \sqrt{\bar{h} / h}$ で表わされる。表一1 最下段は, この值と, 真の値とを比較したもので あるが $10 \%$ 程度の誤差は免がれない。従つて, 実際の地震によつてダ ムと作用する動水圧を計算する場合には，この誤差の範囲内々ある共振 週期の内，最も大きな動水压を生ずるすのを取れば安全側である。

次江，ダム表面各部作用する動水圧の分布は，第 1 次振動型江近似

\section{表一1 種々な断面の共振週期 $(h=100 \mathrm{~m})$}

(1) 短形断面

\begin{tabular}{|c|c|c|c|c|}
\hline$m$ & 0 & 1 & 2 & 3 \\
\hline & $0.278 \mathrm{sec}$ & 0.093 & 0.055 & 0.040 \\
\hline
\end{tabular}

(2) 半口形断面

\begin{tabular}{|c|c|c|c|c|}
\hline$n$ & 1 & 2 & 3 & 4 \\
\hline 0 & $0.237 \mathrm{Sec}$ & 0.082 & 0.051 & 0.037 \\
\hline 1 & 0.104 & 0.054 & 0.038 & 0.030 \\
\hline 2 & 0.067 & 0.041 & & \\
\hline
\end{tabular}

(3) $1 / 4$ 月形断面

\begin{tabular}{|c|c|c|c|c|}
\hline & 矩柇断面 & 半月形断通 & 14 & 勧 \\
\hline 理詥值 & $0.278 \mathrm{se}$ & 0.237 & 0.202 & \\
\hline 近似值 & 10.278 & 0.246 & 0.208 & 0.196 \\
\hline
\end{tabular}

\begin{tabular}{|c|c|c|c|c|}
\hline$n$ & 1 & 2 & 3 & 4 \\
\hline 0 & $0.202 \sec$ & 0.092 & 0.062 & \\
\hline 1 & 0.081 & 0.052 & & \\
\hline 2 & 0.052 & & & \\
\hline
\end{tabular}

(4)三角形断面

\begin{tabular}{|c|c|c|c|c|}
\hline$x$ & 1 & 2 & 3 & 4 \\
\hline 0 & $0.181 \operatorname{Sec}$ & 0.079 & 0.050 & 0.037 \\
\hline
\end{tabular}

第/次共振週期的近似值 したるのとなるであろう。図一 7 ほ, 種々な断面の場合の動水 圧の鉛直並びそ水平分布を，地 震週期を $1 \mathrm{sec}$ として, 定常振 動論によつて求めたものであ る。これらの分布の内, 第 1 次 振動型のものが，その大部分を 占める。矩形断面の動水圧が最 も大きな值を示しているから， 他の断面沉いて子, 矩形断面 の場合の值を標準に取れば安全 側である。従つて, 今, 動水圧 の鉛直分布を放物線之仮定すれ ば，第 1 次共振週期が $T_{1}$ なる 断面のダム海用する動水圧

図一7動水圧に及ぼす地形の影響

Fig.7 Effect of Section of Valley upon Dynamic Water Pressure

(a) 種及今断面

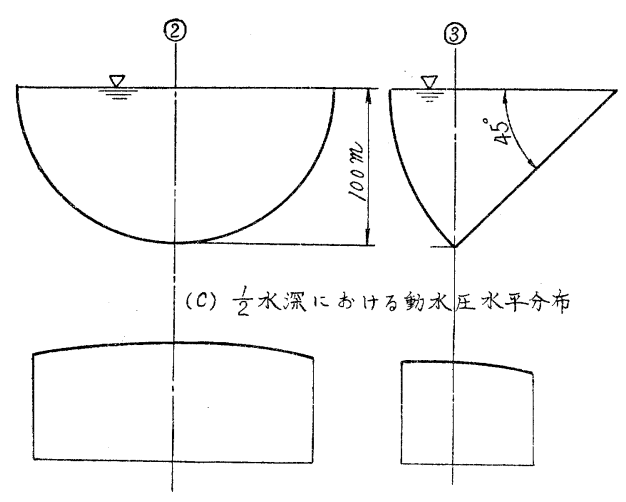

(4)

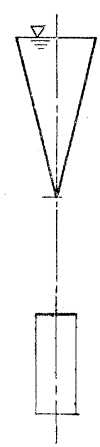

(b) 最深部における 動水圧铅直分布

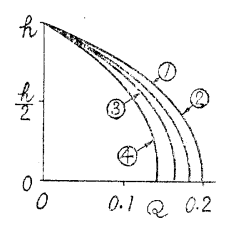

$\sigma=4 \alpha w_{0} k Q$

(1)短形断面 (2)果及形断面 (3) $\frac{1}{4}$ 月形断面 (4)三角形断面 
は，近似的に次式で表わされることになる。

$$
\sigma=4 \propto w_{0} h \cdot \sqrt{1-\frac{z}{h}} \cdot \frac{v}{\pi h} \int_{0}^{t} \psi(t-\tau) J_{0}\left(\frac{2 \pi \tau}{T_{1}}\right) d \tau
$$

\section{[III ] アーチダムへの適用}

アーチダムに対しては，両岸の交角及び傾斜などを考慮して現象を理論的に解明することはほとんぞ不可能で あるが，重力ダムに対して得られた結果から大体の推論を行う。

著者は前論文 ${ }^{2)}$ で, 断面が矩形の場合には, 河流方向震動に対してアーチダムと㗢らく動水圧の水平分布は, 拱 項で最小值を示し，アバットに向うに従つて多少増大した值となること，及び 共振週期が二次元論による共振週 期に等しいことを示した。従つて, 兩岸が注とんど平行と見なされる場合には, 動水圧の水平分布を等布と仮定 して，(30）式がそのまま，アーチダムへも適用できるであろう。両岸の傾斜飞よる共振週期の変化は，［II ] 飞 括ける近似法をとのます用いるものとする。

乙かしながら，両岸の交角が増大すれば，時間函数が異なることが予想されるが，正解が得られない限り不明 であり, 将来の研究に待ちたい。な扬, 流直角方向震動に対しては, 動水圧は極めて小さいるのであるから, 外力として問題にする必要はないと思う。

\section{$[\mathbf{I V}]$ 結論}

以上そより, 著者は, 全く不規則な地震動とよつて重力ダムそ作用する動水圧の理論的解法を, 二次元の場合 及び簡単な地形の場合飞対して導き，その結果から，任意の断面の場合の近似計算式を求め，さら飞, ア一チダ ムに作用する動水圧への忘用を提案した。近似計算式には，余りに推論的と思われる点もあるが，将来の研究に 待らたい。

しかしながら, いずれそしても, 不規則な地動による動水圧は, 従来の定常振動論による動水圧が, 地震加速 度と同一位相で, その時刻の地震加速度に比例して生ずると仮定して求められたものと，はなはだ異なるもので あることがわかつた。

アーチダムの耐震性を論ずる場合，ダム自身の振動性状の重要なことは言うまでもないが，先ずダムに働らく 外力を明白にしなケればならない。満水時アーチダムそ働らく外力は, 堤体慣性力と, 動水圧である。この内前 者は, 地震加速度飞比例した慣性力が, 加速度と同一位相で働らくと見なされるが, 後者は, 前述のように, そ の大きさ及び位相が，地震加速度と必ずしも一致せず，同一地震記録に対しても，堤高及び地形によつてはなは だ異なつた值を示し，かつ，場合によつては相当大きな值となることがわかる。

アーチダムのように比較的薄い構造物では，それ自身の慣性力よりも，動水圧の方が外力の過半を占めるるの であるから，動水圧の性状を明らか、することは，アーチダムの耐震性研究に重要なととである。

著者は, 前述の理論にもとづいて, ダム地点の種々の地震記録汇対して動水圧を求め, アーチダムの而震設計 に資したいと考觉ている。そのためには，(30）式の積分を簡単に行う必要があり，その積算計を目下試作中であ， るが，これについては別の機会にゆづる。

な抢, 本諭文は, 九大工学部土木工学教室田中吉郎教授, 並びそ, 同応用理学教室渡部信夫教授飞御指導をい、 ただいた。ここに厚く感謝の意を表する。

文献

1）畑野 正「重力堰堤に動作する地震力の影響（その二）」土木学会論文集, 昭和 22,23 年度

2) 小坪清真「アーチダムに㗢らく地震時動水動」土木学会論文集第 44 号

3) Watson "Theory of Bessel Function" p. 380

（昭.31.12.7） 